\title{
Potensi Mikoriza Vesikular Arbuskular (MVA) sebagai Biofertilizer pada Tanaman Jagung (Zea mays)
}

\section{Potential of Arbuscular Vesicular Mycorrhiza (MVA) as Biofertilizer in Corn Plants (Zea mays)}

\author{
Kuntum Febriyantiningrum ${ }^{1 *}$, Dwi Oktafitria ${ }^{1}$, Nia Nurfitria ${ }^{2}$, Nurul Jadid ${ }^{3}$, Dewi \\ Hidayati $^{3}$ \\ ${ }^{1}$ Program Studi Biologi, Fakultas Matematika dan Ilmu Pengetahuan Alam, Universitas PGRI Ronggolawe \\ Jl. Manunggal No. 61 Tuban, Jawa Timur, Indonesia \\ ${ }^{2}$ Program Studi Matematika, Fakultas Matematika dan Ilmu Pengetahuan Alam, Universitas PGRI \\ Ronggolawe \\ Jl. Manunggal No. 61 Tuban, Jawa Timur, Indonesia \\ ${ }^{3}$ Program Studi Biologi, Departemen Biologi, Institut Teknologi Sepuluh Nopember \\ Jl. Raya Keputih Sukolilo- Kampus ITS Sukolilo Surabaya, Jawa Timur, Indonesia \\ Email: kuntum060290@gmail.com*Penulis Korespondensi
}

\begin{abstract}
Mining activities can cause environmental damage, and needs land rehabilitation efforts. One approach to land rehabilitation after mine is with repairing the ecosystem condition by improving the quality of the soil, with increase fertility and enriching soil nutrient content by providing a biofertilizer from microbe, such as mycorrhizal fungi. This study aims to determine the potential use of vesicular arbuscular mycorrhizal fungus (MVA) as a biofertilizer by examining the effect of MVA on the growth of corn plant (Zea Mays). Applicated indigenus MVA was able to increase the absorption of phosphorus $(P)$ nutrients in the soil by corn plant so it had an effect on increasing the height and diameter of the corn plant stalks. MVA has the potential as a basic material for making biofertilizer, so it can be used to improve soil quality and environment in ex-limestone mining areas.
\end{abstract}

Keywords: Mycorrhiza, MVA, Biofertilizer, Land Rehabilitation, Corn Plants

\begin{abstract}
Abstrak
Aktivitas pertambangan dapat mengakibatkan kerusakan lingkungan sehingga memerlukan upaya rehabilitasi lahan. Salah satu upaya rehabilitasi lahan pasca tambang adalah dengan memperbaiki kondisi ekosistem dengan meningkatkan kualitas tanah, yaitu meningkatkan kesuburan dan memperkaya kandungan unsur hara tanah dengan pemberian pupuk hayati (biofertilizer) yang terdiri atas mikroba, seperti jamur mikoriza. Penelitian ini bertujuan untuk mengetahui potensi penggunaan jamur mikoriza vesikular arbuskular (MVA) sebagai biofertilizer dengan mengkaji pengaruh pemberian MVA terhadap pertumbuhan tanaman jagung (Zea mays). Pemberian MVA indigenus mampu meningkatkan penyerapan unsur hara fosfor (P) dalam tanah oleh tanaman sehingga berpengaruh terhadap penambahan tinggi dan diameter batang tanaman jagung. MVA berpotensi sebagai bahan dasar dalam pembuatan biofertilizer, sehingga dapat digunakan untuk meningkatkan kualitas tanah dan lingkungan pada lahan bekas tambang batu kapur.
\end{abstract}

Kata kunci: Mikoriza, MVA, Biofertilizer, Rehabilitasi Lahan, Tanaman Jagung

Diterima: 19 Januari 2021, disetujui: 30 Januari 2021

\section{Pendahuluan}

Aktivitas pertambangan dapat mengakibatkan perubahan lingkungan tidak terkecuali tambang batu kapur, seperti perubahan kimiawi tanah dan air, perubahan fisik seperti perubahan morfologi dan topografi lahan, dan perubahan biologi seperti munculnya gangguan pada habitat flora dan fauna serta penurunan produktivitas tanah (Oktafitria et al., 2019). Perubahan ini dapat 
menyebabkan hilangnya fungsi ekologis lahan bekas tambang kapur sehingga memerlukan kegiatan rehabilitasi untuk mengembalikan ekosistem ke kondisi awal dan mengembalikan fungsi lahan sebagaimana mestinya.

Menurut Latifah (2003), kegiatan utama dalam proses rehabilitasi lahan pasca tambang batu kapur terdiri dari pemulihan lahan untuk memperbaiki kondisi ekosistem yang terganggu dan persiapan lahan untuk pemanfaatan selanjutnya. Lahan pasca tambang batu kapur yang tidak direhabilitasi biasanya akan mengalami proses suksesi yang cukup lambat. Hal ini diakibatkan oleh kandungan unsur hara dan mineral yang relatif sedikit di dalam tanah.

Kandungan unsur hara merupakan unsur penting dalam proses pertumbuhan tanaman. Jika tanah pada lahan tambang batu kapur terus menerus digali, maka lama kelamaan lahan tersebut dapat kehilangan lapisan tanah atas (top soil), akibatnya tingkat kesuburan tanah menurun. Salah satu cara untuk meningkatkan kesuburan tanah adalah memperkaya kandungan unsur hara tanah dengan pemberian pupuk hayati (biofertilizer) yang terdiri atas mikroba, seperti jamur mikoriza.

Jamur mikoriza merupakan hasil simbiosis mutualisme antara jamur/cendawan (Myces) dengan sistem perakaran tanaman tingkat tinggi (rhizae). Dalam simbiosis ini, jamur mikoriza mendapatkan karbohidrat dan nutrisi dari tanaman inang serta penyerapan unsur hara oleh tanaman inang. Menurut Sukiman (2015), adanya mikoriza dalam sistem perakaran tanaman dapat membantu penyerapan unsur hara makro dan mikro terutama fosfat $(\mathrm{P})$ dan menghasilkan zat pengatur tumbuh (hormon) untuk menstimulasi pertumbuhan tanaman. Jamur mikoriza berperan dalam mempertahankan stabilitas ekosistem dan keanekaragaman hayati (mempercepat terjadinya suksesi alamiah pada habitat yang memiliki gangguan ekstrim) serta memperbaiki struktur tanah (merupakan penghubung transfer karbon dari akar ke organisme tanah lainnya, misalnya bakteri penambat nitrogen dan bakteri pelarut fosfat). Selain itu, mikoriza juga dapat digunakan sebagai bioindikator untuk menentukan kualitas lingkungan.

Mikoriza vesikular arbuskular atau biasa dikenal dengan MVA merupakan mikroorganisme yang dapat membantu pertumbuhan dan perkembangan tanaman sekitar lahan tambang batu kapur. MVA dimungkinkan akan memiliki peran positif terhadap pertumbuhan tanaman di lahan kering karena dapat berperan sebagai biofertilizer (pupuk hayati), bioprotektor (pestisida hayati) dan bioregulator (katalisator hayati yang menjadikannya sebagai agen biologi yang bersifat ramah lingkungan (Octavianti \& Ermavitalini, 2014; Rahmawati \& Nurhidayati, 2013).

Menurut Peraturan Menteri Pertanian Republik Indonesia Nomor 70/PERMENTAN /SR.140/10/2011 tentang pupuk organik, biofertilizer dan pembenah tanah (Deptan, 2010), "biofertilizer atau pupuk hayati adalah produk biologi aktif yang terdiri atas mikroba yang dapat meningkatkan efisiensi pemupukan, kesuburan dan kesehatan tanah", sehingga mikoriza merupakan salah satu contoh materi biofertilizer.

Biofertilizer MVA merupakan pupuk hayati yang berasal dari pengkulturan mikoriza yang telah diisolasi dari lokasi tertentu, dilanjutkan dengan metode ekstraksi, dan trapping untuk perbanyakan koloni mikoriza. Pembuatan biofertilizer dari mikoriza indigenus (lokal) menjadi salah satu upaya yang dapat dilakukan untuk meningkatkan produktifitas lahan dan tanaman, seperti tanaman jagung (Zea mays). Peran mikoriza sebagai biofertilizer sangat penting dalam proses pemulihan dan peningkatan produktivitas lahan secara berkelanjutan terkait dengan ketersediaan hara serta mengurangi penggunaan pupuk anorganik dan bahan energi berbahan fosil. Pada lahan revegetasi pasca tambang batu kapur PT. Semen Indonesia (Persero) Tbk. (SIG), diketahui terdapat 4 genus dari 13 genus MVA diantaranya Glomus, Acaulospora, Gigaspora, dan Scutellospora. Pencampuran beberapa genus yang ditemukan pada lahan revegetasi tersebut merupakan MVA lokal yang berpotensi sebagai biofertilizer. (Oktafitria et al., 2019).

Manfaat MVA lokal dari lahan pasca tambang batu kapur belum dikaji, sehingga perlu dilakukan penelitian terkait pengkajian potensi MVA lokal tersebut dalam penelitian ini. Tujuan penelitian ini adalah untuk mengetahui potensi MVA sebagai biofertilizer yang akan dikaji pengaruh pemberian MVA terhadap pertumbuhan tanaman jagung (Zea mays). Hasil penelitian ini diharapkan dapat 
menjadi referensi mengenai pemanfaatan MVA lokal yang berasal dari lahan revegetasi pasca tambang batu kapur sebagai pupuk alami untuk menunjang pertumbuhan dan meningkatkan produktivitas tanaman lokal sehingga dapat tercapai ekosistem yang lebih stabil.

\section{Metode Penelitian}

Penelitian dilakukan di lahan revegetasi pasca tambang batu kapur SIG Kecamatan Kerek, Kabupaten Tuban, Provinsi Jawa Timur, Indonesia pada bulan Maret - Oktober 2018. Penelitian ini merupakan penelitian eksperimental menggunakan Rancangan Acak Kelompok (RAK) menggunakan satu faktor yaitu pemberian biofertilizer mikoriza vesikular arbuskular (MVA) dengan 3 kali pengulangan.

Pembuatan biofertilizer MVA dilakukan dengan mengekstraksi spora dari campuran berbagai jenis MVA indigenus yang ditemukan pada tahap eksplorasi dari tanah pada lahan revegetasi pasca tambang kapur (Oktafitria, et al., 2019). Setelah didapatkan ekstrak spora mikoriza, dilakukan pengenceran spora yang nantinya akan dimasukkan ke dalam sistem perakaran tanaman inang bersamaan dengan pemindahan benih yang telah disiapkan.

Tanaman inang dalam penelitian ini adalah jagung (Zea mays). Proses pembenihan dimulai pada bulan Juni 2018dengan menanam benih tanaman inang pada pot pembenihan (seedling tray) kemudian dipindahkan pada pot yang telah disediakan setelah muncul daun pertama (berumur 2 minggu). Selanjutnya, pada awal bulan Juli 2018, tanaman jagung ditumbuhkan pada 2 perlakuan, yaitu: perlakuan pertama diberi penambahan MVA dan perlakuan kedua (kontrol) tanpa penambahan MVA dengan tiga (3 kali pengulangan). Pada perlakuan pertama, isolat spora MVA ditambahkan sebanyak $10 \mathrm{ml}$ di sekitar perakaran tanaman jagung yang telah dipindahkan dari seedling tray. Tanaman jagung dipelihara selama 3 bulan terhitung pada Juli 2018 sampai September 2018 dengan masa penyiraman rutin dua kali sehari selama 2 bulan pertama dan pada bulan ke 3 dilakukan pencekaman kekeringan dengan tidak melakukan penyiraman sama sekali.
Pengamatan dan pengukuran pertumbuhan tanaman hanya dilakukan pada fase vegetatif tanaman dan dilakukan setiap 10 hari dimulai pada tanggal 18 Juli 2018 sampai tanggal 6 September 2018. Pengamatan ini meliputi pengukuran tinggi tanaman dan diameter batang. Setelah memasuki fase generatif, tanaman jagung dibiarkan tumbuh tanpa penyiraman atau perlakuan apapun. Perlakuan ini bertujuan untuk memulai fase pencekaman sehingga dapat diketahui peran atau potensi penggunaan MVA sebagai biofertilizer. Pengukuran parameter fisika kimia, yaitu: suhu, $\mathrm{pH}$, dan kelembaban tanah juga dilakukan untuk mengkaji pengaruhnya terhadap pertumbuhan tanaman jagung.

Data hasil pengukuran tinggi dan diameter tanaman jagung kemudian dianalisis secara deskriptif kualitatif dan diuji dengan uji normalitas untuk mengetahui kelayakan data penelitian. Jika hasil data yang diperoleh normal, dilanjutkan dengan analisis uji T untuk membandingkan hubungan antara perlakukan yang diberikan dengan hasil penelitian sehingga dapat diperoleh akurasi hasil penelitian yang signifikan.

\section{Hasil dan Pembahasan}

Berdasarkan proses isolasi dan identifikasi mikoriza vesikular arbuskular yang telah dilakukan pada penelitian sebelumnya, ditemukan 4 genus dari 13 genus MVA, yaitu: Glomus, Acaulospora, Gigaspora, dan Scutellospora (Oktafitria, et al, 2019). Biofertilizer yang dibuat pada penelitian ini merupakan hasil ekstraksi campuran beberapa jenis MVA yang diperoleh dari isolasi mikoriza yang terdapat pada lahan revegetasi pasca tambang SIG.

Penggunaan tanaman jagung sebagai tanaman uji didasarkan pada jenis tanaman yang umumnya ditanam oleh sebagian besar petani di sekitar lokasi lahan revegetasi pasca tambang SIG. Tanaman jagung memiliki umur pendek dan tahan dalam berbagai kondisi. Indikator yang diamati untuk melihat potensi MVA sebagai biofertilizer pada tanaman jagung (Zea mays) adalah pertumbuhan tanaman yang meliputi tinggi dan diameter batang.

Berdasarkan Tabel 1 dapat diketahui bahwa tanaman jagung yang diberi perlakuan 
penambahan biofertilizer MVA memiliki pertumbuhan tinggi dan diameter batang tanaman yang berbeda tetapi tidak menunjukkan hasil yang signifikan. Berdasarkan hal tersebut dapat diketahui bahwa pemberian MVA sebagai biofilter pada tanaman jagung ternyata memberikan pengaruh yang tidak nyata. Hal ini dapat disebabkan karena pemberian dosis MVA yang kurang sesuai serta adanya faktor lain yang berpengaruh seperti faktor lingkungan dan unsur hara yang terkandung di dalam media tanam.

Tabel 1. Rerata pertumbuhan tinggi tanaman jagung (dalam $\mathrm{cm}$ )

\begin{tabular}{lrrrrrr}
\hline \hline Pengukuran ke- & $\mathbf{1}$ & $\mathbf{2}$ & $\mathbf{3}$ & $\mathbf{4}$ & $\mathbf{5}$ & $\mathbf{6}$ \\
\hline \hline Kontrol & 52.17 & 93.33 & 129.00 & 149.83 & 155.67 & 156.00 \\
Pemberian MVA & 49.00 & 94.83 & 135.50 & 155.00 & 158.83 & 162.33 \\
\hline \hline
\end{tabular}

Tabel 2. Rerata pertumbuhan diameter tanaman jagung (dalam $\mathrm{cm}$ )

\begin{tabular}{lcccccc}
\hline \hline Pengukuran ke- & $\mathbf{1}$ & $\mathbf{2}$ & $\mathbf{3}$ & $\mathbf{4}$ & $\mathbf{5}$ & $\mathbf{6}$ \\
\hline \hline Kontrol & 9.96 & 11.92 & 13.75 & 14.81 & 12.02 & 10.39 \\
Pemberian MVA & 7.94 & 9.93 & 11.98 & 14.05 & 12.39 & 10.03 \\
\hline \hline
\end{tabular}

Menurut Hartanti (2014), pertumbuhan tanaman jagung lebih dipengaruhi ketersediaan unsur hara seperti unsur $\mathrm{N}$ yang berfungsi membentuk protein dalam pertumbuhan tanaman pada fase vegetatif. Selain itu, faktor lingkungan seperti suhu juga dapat memengaruhi pertumbuhan tanaman jagung karena berhubugan dengan produksi dan transportasi nutrisi yang dubutuhkan oleh tanaman (Fitter \& Hay, 1994). Meskipun demikian, pengkajian ulang terkait pemanfaatan MVA sebagai pupuk organik hayati perlu ditinjau ulang supaya memperoleh hasil yang maksimal sehingga MVA dapat dimanfaatkan.

Pertumbuhan tanaman merupakan salah satu indikator yang dapat diamati untuk mengetahui pengaruh pemberian mikoriza vesikular arbuskular (MVA) sebagai biofertilizer pada tanaman. Berdasarakan Tabel 1 dan Tabel 2, data tersebut menunjukkan bahwa tanaman jagung yang diberi tambahan MVA sebagai biofertilizer dapat tumbuh dengan baik dan lebih tinggi jika dibandingkan dengan tanaman jagung yang tidak diberikan penambahan biofertilizer MVA meskipun tidak berbeda nyata. Dosis pemberian MVA ke dalam tanaman juga akan berpengaruh terhadap pertumbuhan tanaman. Tanaman yang diinfeksi dengan MVA akan memiliki kandungan unsur hara yang lebih tinggi, karena MVA dapat menyediakan unsur hara dalam tanah. Selain itu, keberadaan MVA membantu pertumbuhan tanaman dengan memperbaiki keterserdiaan hara fosfor dan membantu meningkatkan pertahanan akar dari serangan patogen. Penambahan biofertilizer MVA terbukti mampu memperbaiki dan meningkatkan kualitas tanah, sehingga mampu meningkatkan pertumbuhan tanaman pada lahan bekas pertambangan maupun lahan kritis secara signifikan (Setiadi, 1991).

Tanaman jagung yang diberi MVA sebagai pupuk hayati mengalami pertumbuhan tinggi tetapi berhenti mengalami pertumbuhan setelah memasuki fase pencekaman (pegurangan penyiraman) dan memasuki fase untuk persiapan perkembangbiakan tanaman. Selama masa pemeliharaannya, tanaman jagung tidak mengalami gangguan penyakit ataupun hama.

Pemberian MVA diberikan dengan cara menuangkan ekstraksi MVA pada sistem perakaran tanaman jagung (Zea mays) dengan tujuan MVA tersebut dapat menginfeksi akar tanaman. Tanaman jagung memiliki sistem perakaran serabut sehingga mudah diinfeksi jika diberi tambahan biofertilizer MVA (Hartanti, 2014). MVA dapat dengan mudah bersimbiosis dengan akar tanaman jagung melalui kolonisasi akar tanaman jagung, kemudian akan memproduksi jalinan hifa secara intensif sehingga tanaman yang mengandung mikoriza mampu meningkatkan kapasitas dalam penyerapan unsur hara (Oktafitria, 2019; Pulungan, 2018). 
Pada dasarnya, MVA memiliki beberapa peranan penting diantaranya sebagai penyedia unsur hara di dalam tanah, pengurai bahan organik dan pembentuk humus sehingga mampu meningkatkan ketersediaan hara di dalam tanah, sebagai pengontrol organisme pengganggu tanaman (OPT), pemantap agregat tanah dan merombak persenyawaan kimia di dalam tanah. Mikoriza memberikan hormon yang dibutuhkan oleh tanaman untuk tumbuh, seperti auksin, sitokinin, giberellin, serta zat pengatur tumbuh kepada tanaman inangnya (Nurhayati, 2012).
Pertumbuhan tinggi tanaman jagung erat kaitannya dengan pertumbuhan diameter batang tanaman. Pada awal pengambilan data diameter batang tanaman, tanaman jagung tumbuh dengan baik, tetapi setelah memasuki fase generatif, diameter batang mulai mengalami penurunan dan semakin menyusut. Menyusutnya diameter batang dapat dipengaruhi oleh ketersediaaan air di dalam tanah. Hal ini disebabkan dengan berkurangnya volume air seiring dengan pengurangan intensitas penyiraman ketika sudah memasuki fase generatif.

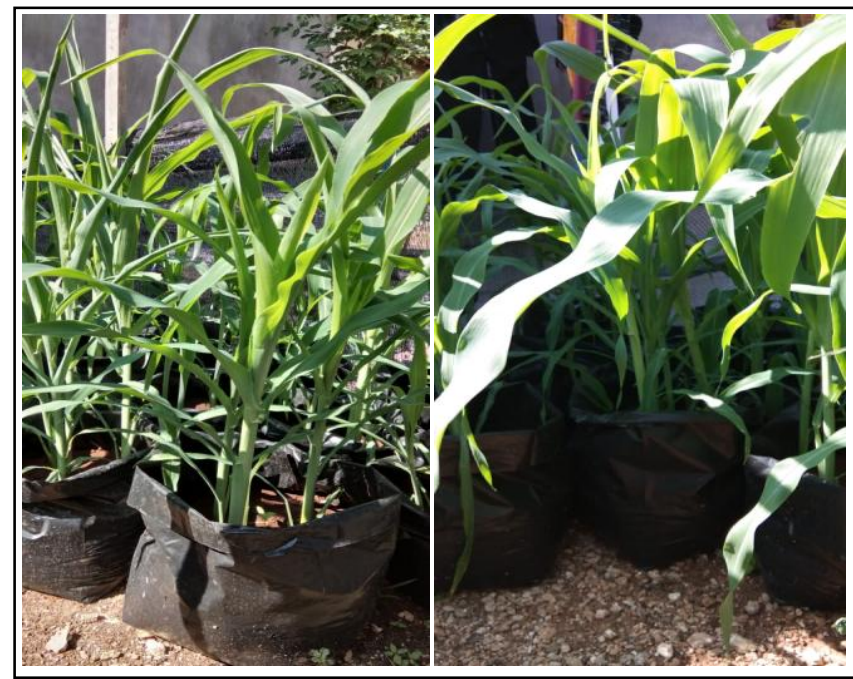

Gambar 1. Kondisi tanaman jagung dengan pemberian biofertilizer MVA pada 10 hari ke-2

Ketika tanaman memsuki fase generatif, , pasokan air akan berkurang sehingga kandungan air di dalam tanah akan ikut berkurang. Hal ini akan mempengaruhi volume batang sehingga batang yang diukur akan mengalami penurunan.

Menurut Hartanti (2014), penambahan diameter batang dipengaruhi oleh ketersediaan unsur hara di dalam tanah, terutama fosfor $(\mathrm{P})$ yang berperan dalam pembelahan dan perkembangan sel-sel tanaman. Pemberian MVA sebagai biofertilizer dapat meningkatkan penyerapan unsur fosfor $(\mathrm{P})$ oleh tanaman. Dalam hal ini, fosfor terlibat dalam pembelahan dan pembentukan sel-sel akar dan batang tanaman. Mikoriza menghasilkan hormon auksin yang berfungsi memacu perpanjangan sel tanaman dan enzim fosfatase yang membantu proses penyerapan unsur hara P (Cruz et al., 1992). Penyerapan unsur hara dilakukan oleh hifa eksternal mikoriza yang menjulur ke dalam tanah, kemudian dimanfaatkan untuk memacu proses fotosintesis. Hasil fotosintesis tersebut akan didistribusikan ke seluruh bagian tanaman untuk pertumbuhan dan perkembangan tanaman (Gardner et.al., 1991).

Pertumbuhan tanaman jagung (Zea mays) juga dipengaruhi oleh faktor lingkungan. Menurut Fitter \& Hay (1994), pertumbuhan tanaman dipengaruhi oleh faktor lingkungan seperti intensitas cahaya dan suhu. Pengukuran parameter fisika kimia dalam penelitian ini meliputi suhu/temperatur, $\mathrm{pH}$ dan kelembaban tanah yang dihitung selama masa pertumbuhan tanaman jagung. Berdasarkan data pengukuran suhu yang diperoleh, neningkatnya temperatur pada awal 40 hari yang kedua disebabkan oleh berkurangnya asupan air pada polibag. Hal ini disebabkan oleh pengurangan intensitas penyiraman yang semula dilakukan setiap hari diubah menjadi 2 hari sekali. Suhu yang tinggi dapat meningkatkan aktivitas MVA pada sistem perakaran tanaman jagung. Di daerah 
yang beriklim tropis seperti Indonesia, hal ini cukup menguntungkan.

Temperatur atau suhu tanah di dalam polibag juga mengalami perubahan selama proses pertumbuhan tanaman jagung. Selama pengamatan, menunjukkan bahwa temperatur tanah berada pada kisaran $25-30^{\circ} \mathrm{C}$. Mulai pada 40 hari kedua, temperatur pada tanah mulai berada pada kisaran diatas $30^{\circ} \mathrm{C}$. Hal ini menunjukkan bahwa kondisi lingkungan tanah sudah mulai stabil dan mendukung pertumbuhan tanaman jagung. Infeksi oleh cendawan mikoriza dapat meningkat seiring naiknya suhu. Suhu yang tinggi pada siang hari $\left( \pm 35^{\circ} \mathrm{C}\right)$ tidak menghambat perkembangan dan aktivitas fisiologis mikoriza, akan tetapi peran mikoriza hanya akan menurun pada suhu di atas $40^{\circ} \mathrm{C}$. Hal ini menunjukkan suhu berpengaruh terhadap pertumbuhan tanaman jagung (Zea mays), tetapi bukan merupakan faktor pembatas utama dari aktivitas mikoriza.

Faktor lingkungan lain yang berpengaruh terhadap pertumbuhan tanaman adalah kelembaban tanah. Kelembaban tanah selama masa pertumbuhan tanaman jagung menunjukkan nilai yang berbanding terbalik dengan temperatur atau suhu tanah. Semakin lembab suatu tanah (wet) maka kandungan air yang berada di dalam tanah tersebut cukup tinggi sehingga tanaman tidak akan kekurangan air untuk mencukupi kebutuhan pertumbuhannya. Nilai kelembaban tanah berbanding terbalik dengan nilai temperatur tanah. Hal ini terlihat bahwa ketika suhu tanah selama pengamatan menunjukkan nilai di bawah $30^{\circ} \mathrm{C}$, maka nilai kelembaban mencapai nilai \pm 10 (wet), sedangkan apabila nilai temperatur diatas $30^{\circ} \mathrm{C}$ maka nilai kelembaban cenderung menurun hingga nilai \pm 4 ( dry).

Selama proses pertumbuhan dan pemeliharaan tanaman jagung dilakukan pengukuran $\mathrm{pH}$ atau keasaman tanah. Berdasarkan pengamatan di lapangan, pada awal masa penanaman kondisi tanah cenderung asam, yaitu memiliki $\mathrm{pH}$ 5. Namun 20 hari setelahnya, $\mathrm{pH}$ tanah cenderung normal \pm 7 . $\mathrm{pH}$ tanah juga memiliki peranan penting dalam kesuburan tanah karena dapat mempengaruhi penyerapan unsur hara makro dan mikro. Kisaran $\mathrm{pH}$ yang optimal untuk pertumbuhan tanaman adalah $\mathrm{pH} 5.5$ sampai 7 karena pada kondisi tersebut proses penyerapan unsur tersebut akan lebih optimal.
Penggunaan MVA sebagai biofertilizer aman digunakan karena tidak menyebabkan kerusakan dan pencemaran lingkungan. Jika MVA tumbuh dengan baik di suatu lahan, maka penggunaan MVA sebagai biofertilizer dapat memberikan manfaat untuk menyuburkan tanah dan memperbaiki lingkungan secara berkelanjutan. Kehadiran MVA diharapkan dapat digunakan sebagai bahan dasar pembuatan biofertilizer atau pupuk hayati dalam upaya rehabilitasi maupun reklamasi lahan pasca tambang kapur.

\section{Simpulan}

Penggunaan mikoriza vesikular arbuskular (MVA) pada tanaman jagung yang diperoleh melalui metode isolasi dan ekstraksi berpotensi sebagai biofertilizer (pupuk hayati) yang dapat membantu pertumbuhan tanaman. Biofertilizer MVA diharapkan dapat membantu proses pertumbuhan tanaman dan meningkatkan kualitas tanah sebagai salah satu bentuk kegiatan rehabilitasi maupun reklamasi lahan pasca tambang batu kapur.

\section{Daftar Pustaka}

Depatremen Pertanian. (2011). Peraturan Menteri Pertanian Republik Indonesia Nomor 70/PERMENTAN /SR.140/10/2011 tentang pupuk organik, biofertilizer dan pembenah tanah.

Fitter ,A.H. and Hay. R.K.M. Fisiologi Lingkungan Tanaman. (1991).Gajah Mada University Press

Gardner, F.P., R.B. Pearce dan R.L.Mitchell. (1991). Fisiologi Tanaman Budidaya. UI Press. Jakarta.

Hajoeningtijas, Oetami, D., Suyadi, \& Aman. (2011). Transfer Teknologi Perbanyakan Biofertilizer Mikoriza pada Petani Sebagai Upaya Mendukung Pertanian Berkelanjutan. Agritech, XIII (2), 125 139.

Harley, J.L. and Smith M. S. (1983). Mycorrhizal Syimbiosis. Academic Press,Inc. New York. 483p.

Hartanti, I. (2014). Pengaruh Pemberian Pupuk Hayati Mikoriza Dan Rock Phosphate Terhadap Pertumbuhan Dan Produksi Tanaman Jagung Manis (Zea mays 
saccharata Sturt). JOMFAPERTA Vol 1 No.1(2014):1-14

Latifah, S. (2003). Kegiatan Reklamasi Pada Lahan Bekas Tambang. Program Ilmu Kehutanan Jurusan Manajemen Hutan. Skripsi. Medan : Universitas Sumatera Utara.

Nurhayati. (2012). Infektivitas Mikoriza Pada Berbagai Jenis Tanaman Inang Dan Beberapa Jenis Sumber Inokulum. Jurnal Floratek, 7, 25 -31.

Nurtjahyani, S.D., Oktafitria, D., Sriwulan, Ashuri, N. M., Cintamulya, I dan Purnomo, E. (2018). Identifikasi dan Karakterisasi Keanekaragaman Mikoriza pada Lahan Reklamasi Bekas Penambangan Batu Kapur di Kabupaten Tuban," in Prosiding Seminar Nasional VI Hayati, pp. 291-299.

Octavianti, E. N. \& Ermavitalini, D. (2014). Identifikasi Mikoriza dari Lahan Desa Poteran, Pulau Poteran, Sumenep Madura. J. Sains POMITS, vol. 3, no. 2, pp. 53-57.

Oktafitria, D., Febriyantiningrum, K., Jadid, N., Nurfitria, N., RahmadanI, F., Amrullah, A., dan Hidayati, D. (2019). Assessment of reclamation success of former limestone quarries in Tuban, Indonesia, based on soil arthropod diversity and soil organic carbon content. Biodiversitas Journal of Biological Diversity, 20(6).

Oktafitria, D., Febriyantiningrum, K., Nurfitria, N., Jadid, N., Purwani, K. I., Sumarsih, N., ... dan Purnomo, E. (2019). Eksplorasi Mikoriza Vesikula Arbuskula (MVA) Pada Lahan Revegetasi Pasca Tambang Batu Kapur Dan Status Infeksinya Terhadap Akar Jagung (Zea mays). Prosiding SNasPPM 4(1), 63-70.

Panda, H. (2011). Manufacture of Biofertilizer and Organic Farming. India: Asia Pascific Business Press Inc.

Pulungan, A.S.S., (2018). Tinjauan Ekologi Fungi Mikoriza Arbuskula. Jurnal Biosains. Vol. 4 No. 1.

Setiadi. (1991). Aplikasi Mikoriza Tanah sebagai salah satu Terapan dalam Bioteknologi Kehutanan, Seminar Rekayasa Genetika (Bioteknologi) IPB, 1991.

Silitonga, C. M. (2011). Pengaruh Kelembaban Tanah Dan Pemberian Kascing Pada Lahan Rawa Pasang Surut Sungai Denai Pada Pertumbuhan Jagung (Zea mays). Skripsi. Dipublikasikan. Diakses melalui http://repository.usu.ac.id/handle/1234567 89/24379 pada 14 April 2020.

Sukiman, H. (2015). Pemanfaatan Mikoriza Untuk Meningkatkan Kualitas Bibit Pohon dan Produktivitas Lahan Kawasan Perkotaan. Prosiding Seminar Nasional Masyarakat Biodiversitas Indonesia. Vol 1 Nomor 8. ISSN: 2407-8050 : hal.2021-2026. 